\title{
The Promoter of the Vicia faba L. Leghemoglobin Gene VfLb29 Is Specifically Activated in the Infected Cells of Root Nodules and in the Arbuscule-Containing Cells of Mycorrhizal Roots from Different Legume and Nonlegume Plants
}

\author{
Martin F. Vieweg, ${ }^{1}$ Martin Frühling, ${ }^{1}$ Hans-Joachim Quandt, ${ }^{1}$ Ute Heim, ${ }^{2}$ Helmut Bäumlein, ${ }^{2}$ Alfred \\ Pühler, ${ }^{1}$ Helge Küster, ${ }^{1}$ and Andreas M. Perlick ${ }^{1}$ \\ ${ }^{1}$ Universität Bielefeld, Fakultät für Biologie, Lehrstuhl für Genetik, P. O. Box 100131, D-33501 Bielefeld, Germany; \\ ${ }^{2}$ Institut für Pflanzengenetik und Kulturpflanzenforschung, Corrensstr. 3, D-06466 Gatersleben, Germany
}

Submitted 24 April 2003. Accepted 6 August 2003.

The VfLb29 leghemoglobin gene promoter was polymerase chain reaction-amplified from a Vicia faba genomic library and was fused to the gusAint coding region. Expression of the chimeric gene was analyzed in transgenic hairy roots of the legumes $V$. faba, V. hirsuta, and Medicago truncatula as well as in transgenic Nicotiana tabacum plants. The VfLb29 promoter was found to be specifically active not only in the infected cells of the nitrogen-fixing zone of root nodules but also in arbuscule-containing cells of transgenic $V$. faba and $M$. truncatula roots colonized by the endomycorrhizal fungus Glomus intraradices. In addition to these two legumes, specific expression in arbuscule-containing cells was also observed in the nonlegume $N$. tabacum. All studies were done in comparison to the $V$. faba leghemoglobin gene promoter $V f L b 3$ that as $V f L b 29$ was expressed in the infected cells of root nodules but showed no activity in endomycorrhiza. An activation of the VfLb29 promoter due to hypoxia in metabolically active tissues was excluded. The conserved activation in arbuscule-containing cells of legumes and the nonlegume $N$. tabacum suggests a conserved trigger for this promoter in legume and nonlegume endomycorrhiza symbioses.

Additional keywords: root transformation.

The symbiotic interaction of $\mathrm{N}_{2}$-fixing soil bacteria of the family Rhizobiaceae and leguminous plants is the best studied system of plant-microbe interactions. By contrast, the molecular research concerning mycorrhiza symbioses is still at an early stage. Both symbioses have to be looked upon as ecological and economical factors of great importance (Jeffries 1987). In contrast to the taxonomically very restricted $\mathrm{N}_{2}$-fixing symbiosis, the majority of higher plants are able to establish symbioses with arbuscular mycorrhizal (AM) fungi of the order Glomales. Mycorrhization offers several benefits to the host plant, including improved nutrition, greater drought resistance, and protection from pathogens (Harley and Smith 1983).

Closer examination of both root nodule formation induced by rhizobia and root colonization by arbuscular mycorrhizal

Corresponding author: H. Küster: E-mail: Helge.Kuester@Genetik.UniBielefeld.DE, Fax: +49(0)521106 5626; Telephone: +49(0)5211064819. fungi reveals several similarities of these two interactions. Both symbioses are characterized by a bidirectional exchange of nutrients with carbon components flowing to the microsymbiont and inorganic nutrients moving to the plant. In both cases, the target tissue for the microsymbiont is the root cortex. Within colonized root cells, the microsymbionts are separated from the host cytoplasm by specific plant-derived membranes and cell wall material (Gianinazzi-Pearson 1996). For the AM symbiosis, the main site of exchange between plant and fungus is the arbuscule, a highly branched structure that is formed by the fungus within inner cortical cells of the root (Harrison 1999). Arbuscules are transient structures, since they develop and subsequently degenerate within 6 to 10 days (Alexander et al. 1989; Dickson and Smith 2001). In case of the $\mathrm{N}_{2}$-fixing symbiosis, the exchange occurs in the rhizobia-infected cells of the nitrogen-fixing zone III of the root nodule (Provorov et al. 2002). Due to the obvious similarities between these two symbiotic interactions and the existence of mutations resulting both in nod $^{-}$and myc $^{-}$phenotypes, it was supposed that the two symbioses share a common genetic basis (Duc et al. 1989; Gianinazzi-Pearson et al. 1997).

Genes particularly involved in the $\mathrm{N}_{2}$-fixing symbiosis have been subdivided into early and late nodulin genes, depending on the onset of their expression during nodule development. Early nodulin genes are expressed after mutual recognition between the plant and the rhizobia and before the start of nitrogen fixation. They are supposed to play a role in the infection process and in nodule organogenesis. Early nodulin genes such as MtEnod11, MtEnod12 (Journet et al. 2001), MsEnod40, MsEnod2 (VanRhijn et al. 1997), PsEnod5, and PsEnod12 (Albrecht et al. 1998) have already been shown to be induced not only during nodulation but also in legume root tissues colonized by mycorrhizal fungi.

The expression of late-nodulin genes is activated around the onset of nitrogen fixation, and these gene products are involved in nodule functioning, which is mainly the metabolic exchange between plant and bacteroid. The most prominent and most thoroughly investigated late nodulins are the leghemoglobins (Lb), which are expressed in the infected cells just before and during nitrogen fixation. These oxygen-binding heme proteins are responsible for supporting the flux of oxygen to the nitrogen-fixing bacteroids. Apart from these symbiotic hemoglobins, several nonsymbiotic hemoglobin genes have been found 
in many legume and nonlegume plant species in recent years (Andersson et al. 1996; Seregelyes et al. 2000; Trevaskis et al. 1997). These genes are expressed in several plant tissues, and many of them were shown to be inducible by hypoxia, suggesting that they are somehow involved in the oxygen supply under this stress condition. However, an active transport of oxygen in this case is not likely due to the oxygen binding kinetics of these proteins (Hill 1998; Hunt et al. 2001). The most recently discovered type of plant hemoglobins are the 2-on-2 hemoglobins that share common structural characteristics with bacterial hemoglobins. The 2-on-2 hemoglobin gene glb3 from Arabidopsis thaliana was found to be expressed throughout the plant, and it was shown that this kind of hemoglobin exists in many plant species (Watts et al. 2001). Remarkably, a 2-on-2 hemoglobin gene from $M$. truncatula was recently shown to be specifically induced in the root nodule (Fedorova et al. 2002).

The leghemoglobin gene VfLb29 from $V$. faba is the first late-nodulin gene that has already been shown to be transcriptionally activated not only in the root nodule but also in roots colonized by an endomycorrhizal fungus. Interestingly, VfLb29 exhibits a significantly low sequence homology to other $V$. faba leghemoglobin genes as well as to leghemoglobin genes from other legumes (Frühling et al. 1997). In this study, we report on further characterizations of this unusual leghemoglobin gene. By the use of promoter-gus fusions in transgenic plant tissues, we were able to demonstrate a specific expression in infected cells of legume root nodules as well as in legume and nonlegume root tissues colonized by the endomycorrhizal fungus Glomus intraradices. To our knowledge, this is the first legume gene that is specifically activated both in infected cells of the root nodule and in arbuscule-containing cells of the root cortex.

\section{RESULTS}

The promoter sequences of $V f L b 29$ and $V f L b 3$ contain motifs characteristic of symbiotic hemoglobin gene promoters.

A 1,261-bp VfLb29 promoter fragment (accession number AJ564166) and a 2,003-bp VfLb3 promoter fragment (acces- sion number AJ001752) were isolated by polymerase chain reaction amplification from an adapter-ligated genomic broad bean library and by screening a genomic library of broad bean, respectively. The promoter fragments were sequenced and subsequently compared by multiple alignments to other symbiotic and nonsymbiotic hemoglobin gene promoters from various species. These database searches revealed that both the VfLb29 and the VfLb3 promoter shows characteristic similarities to symbiotic hemoglobin promoters. Common with other known leghemoglobin promoters, the VfLb29 and VfLb3 promoters exhibit the two consensus sequence motifs 'AAAGAT' and 'CTCTT' (Fig. 1). These motifs are characteristic elements of leghemoglobin and other nodulin gene promoters with respect to their expression in the infected cells of the root nodule tissue. These two motifs are part of the 'organ-specific element' (OSE) sequences originally identified in the soybean leghemoglobin $l b c 3$ promoter reported by Stougaard and associates (1987). By contrast, the sequence motif 'GAAGAG', characteristic of nonsymbiotic hemoglobin gene promoters, is not present in any of the two leghemoglobin promoter sequences isolated. Thus, on the nucleotide level, the VfLb29 promoter shows typical characteristics of a symbiotic leghemoglobin promoter.

\section{The $V f L b 29$ and $V f L b 3$ promoters are active}

in infected cells of $V$. faba and $M$. truncatula root nodules.

In order to study the expression properties of both $L b$ promoters during symbiotic nitrogen fixation, chimeric $\mathrm{p} L b 29$ gusAint and $\mathrm{p} L b 3$-gusAint constructs were inserted into the $\mathrm{T}$ DNA (transfer-DNA) of the root-inducing (Ri) plasmid of Agrobacterium rhizogenes ARqual (Quandt et al. 1993). In case of the VfLb29 promoter, two fragments ranging from 1,261 to -31 and -987 to -31 were tested in all approaches. Since both fragments led to comparable patterns of gene expression (data not shown), the results presented below are based on the -987 to $-31 \mathrm{pLb29-gusAint} \mathrm{fusion.} \mathrm{For} \mathrm{the} \mathrm{study}$ in the homologous legume $V$. faba and the heterologous legume $M$. truncatula, an induction of transgenic roots was performed by an improved method in open pots, based on the protocol de-

Vicia faba, VfLb29 TATTATTTTAAAAGATAA_TTGTCTCTTAGC_AATGACAATGGC_CATCTCTA -152

Symbiotic hemoglobins:

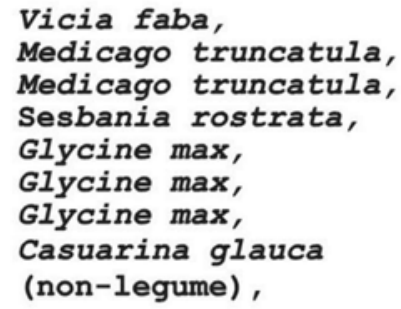

GTCTTTTTAAAAAGATTC TTGTCTTTTTAATAATGCCAATGGT TAGTTTTTGAAAAGTTTT ${ }^{-}$TTGTCTCTT AATAACTACAATGGT AAGTTTTTTAAATGATTA TTGTCTCTT ${ }^{-}$AATAATGTCAACAGC TAAATTTTTAAAAGATTA TTGTCTCTT ${ }^{-}$AATAATGTCAATGGC AAGTTTTTGAAAAGATGA TTGTCTCTTCACCATACCAATTGAT AGGATTTTGAAAAGATCA TTGGCTCTTCGTCATGCCGATTGA AAGATTTTGAAAAGATCATTTGGCTCTTCATCATGCCGATTGA
CATTTCCA -154 CACCTCCA -112 CATTTCCA -115 CACCCTTC -165 CACCCTCC -104 CACCCTCC -91 САСССТС -91

\section{Nonsymbiotic hemoglobins:}

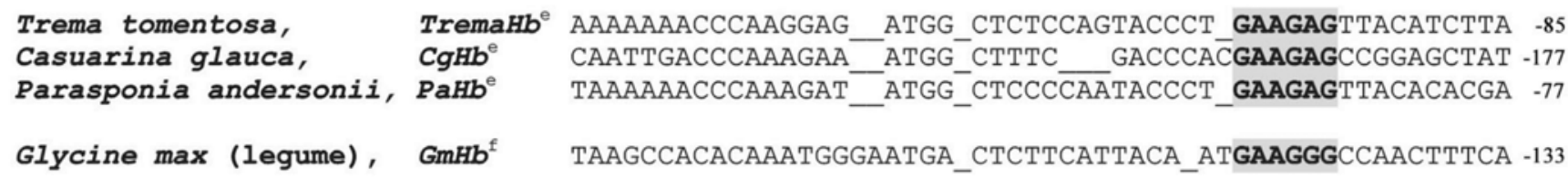

Fig. 1. Alignment of promoter sequences from different symbiotic and nonsymbiotic hemoglobin genes. The consensus sequence motifs of organ-specific elements characteristic of the promoters activated in infected cells of root nodules and the common motif of the nonsymbiotic hemoglobin promoters are highlighted. The positions of the motifs are marked by boxes. Numbers indicate the distance from the translation initiator ATG (VfLb29, VfLb3, $C g s y m H b$, $\mathrm{CgHb}$ ) or the distance from the transcription initiation site (MtLb1, MtLb2, SrgLb3, GmLbc1, GmLbc2, GmLbc3, TremaHb, PaHb, GmHb). References indicated by superscript letters: a, Gallusci et al. 1991; b, Metz et al. 1988; c, Stougaard et al. 1987; d, Jacobsen-Lyon et al 1995; e, Christensen et al. 1991; and f, Andersson et al. 1996. 
scribed by Quandt and associates (1993). This improved method was originally developed for the induction of hairy roots on $\mathrm{V}$. faba, since this species is difficult to cultivate under sterile conditions, due to its size. However, this method also proved to be a simple and effective way to induce hairy roots on other legume species, such as M. truncatula (discussed below).

After the induction of hairy roots, the plants were inoculated with Rhizobium leguminosarum VF39 (Priefer 1989) and Sinorhizobium meliloti 1021 (Casse et al. 1979). After four weeks, V. faba and M. truncatula plants transformed with either construct were histochemically analyzed for $\beta$-glucuronidase (GUS) activity in roots and different stages of nodule development. Both $L b$ promoter-gus fusions showed a strong GUS activity in the infected cells of the nitrogen-fixing zone of mature nodules and only a low level of GUS activity in the interzone II-III of mature nodules (Fig. 2A, B, and C). These results were obtained both in the homologous legume $V$. faba (Fig. $2 \mathrm{~A}$ and B) and the heterologous legume M. truncatula (Fig. 2C and D). Figure 2D documents in more detail the restriction of GUS activity to the infected cells of $M$. truncatula root nodules. GUS activity during earlier stages of nodule development, as described for the leghemoglobin gene $V s L b 1$ (Heidstra et al. 1997), was not observed (Fig. 3A, arrow). The expression patterns of $\mathrm{pLb29}$ gusAint and $\mathrm{pLb3}$-gusAint can be looked upon as an activity that is typical of leghemoglobin promoters.

\section{The $V f L b 29$ promoter shows activation \\ in arbuscule-containing root cells of $V$. faba, V. hirsuta, and M. truncatula plants colonized by the mycorrhizal fungus $G$. intraradices.}

Since Northern hybridizations demonstrated that VfLb29 transcripts are not only present in root nodules but also in root tissues colonized by the endomycorrrhizal fungus G. fasciculatum (Frühling et al. 1997), our main interest was to examine in detail the activity of the VfLb29 promoter during this symbiotic interaction. We made use of pVfLb29-gusAint and $\mathrm{pVfLb3}$ gusAint transgenic hairy roots of $V$. faba, V. hirsuta, and $M$. truncatula, obtained as mentioned before. After root transformation, the plants were inoculated with the arbuscular mycorrhizal fungus $G$. intraradices. Approximately four weeks after inoculation, colonized roots were harvested for histological GUS-staining and were examined by light microscopy. In the case of roots transformed with the pVfLb3-gusAint construct, no GUS-staining above an occasional unspecific background was observed. By contrast, the examination of transgenic hairy roots carrying the $\mathrm{p} V f L$ b29-gusAint fusion revealed inner cortical cells with intense and specific gus expression (Fig. 3A, B, $\mathrm{C}$, and D). For a closer look at these inner cortical cells, additional semithin sections of about $80 \mu \mathrm{m}$ were performed (Fig. $3 \mathrm{~A}$ and B). To confirm that the VfLb29 promoter is activated in root segments colonized by the fungus, the GUS-stained roots and semithin sections were subsequently treated with chlorazole black $\mathrm{E}$ (CBE), which visualizes fungal structures within the root tissue. The double-staining revealed that both the gus expression and the CBE-staining were mainly restricted to arbuscule-containing cells (Fig. 3F). Neither root tips, nodule primordia, nor other root tissues showed GUS activity (Fig. 3A, arrow, and C). In some cases, a weak GUS-staining was also observed in closely surrounding cells. This might reflect different stages of arbuscule development (Fig. 3E, arrows). As a control, wild-type roots were also examined, and no gus expression was observed in cells containing an arbuscule (data not shown). As in the case of the nodule symbiosis, the expression patterns observed were very similar in V. faba, V. hirsuta, and $M$. truncatula, and a low variability was observed in a large number of independent hairy roots of all species. Thus, the presence of $V f L b 29$ transcripts in mycorrhizal roots of $V$. faba shown by Frühling and associates (1997) was now extended to the cellular level by the localization of specific promoter activity in arbuscule-containing cells.

\section{The $V f L b 29$ promoter is active in root cells} of the nonlegume $N$. tabacum that contain an arbuscule.

Symbiotic Lb were supposed to be specialized proteins with a specific function in the root nodule (Appleby 1984). The nodulation-independent activation of a leghemoglobin gene during the mycorrhiza symbiosis, as shown here for VfLb29, led to the question whether the VfLb29 promoter might also be activated under mycorrhization in a nonlegume incapable of forming nodules. To answer this question, pVfLb29-gus transgenic tobacco plants were generated by A. tumefaciens-mediated transformation. Again, the pVfLb3-gusAint construct was used as a control. For investigations of promoter activities, the plants obtained were inoculated with $G$. intraradices spores and were grown in pots comparable to the treatment of the legume plants mentioned before. Following GUS-staining, the VfLb29 promoter in N. tabacum showed the same specific activation in arbuscule-containing cells (Fig. 3F) that had been observed before in the case of $V$. faba, V. hirsuta, and M. truncatula. This was again verified by additional CBE-staining (data not shown). In accordance to the results in legumes, tobacco wild-type and pVfLb3-gusAint mycorrhizal roots showed no GUS-staining (data not shown).

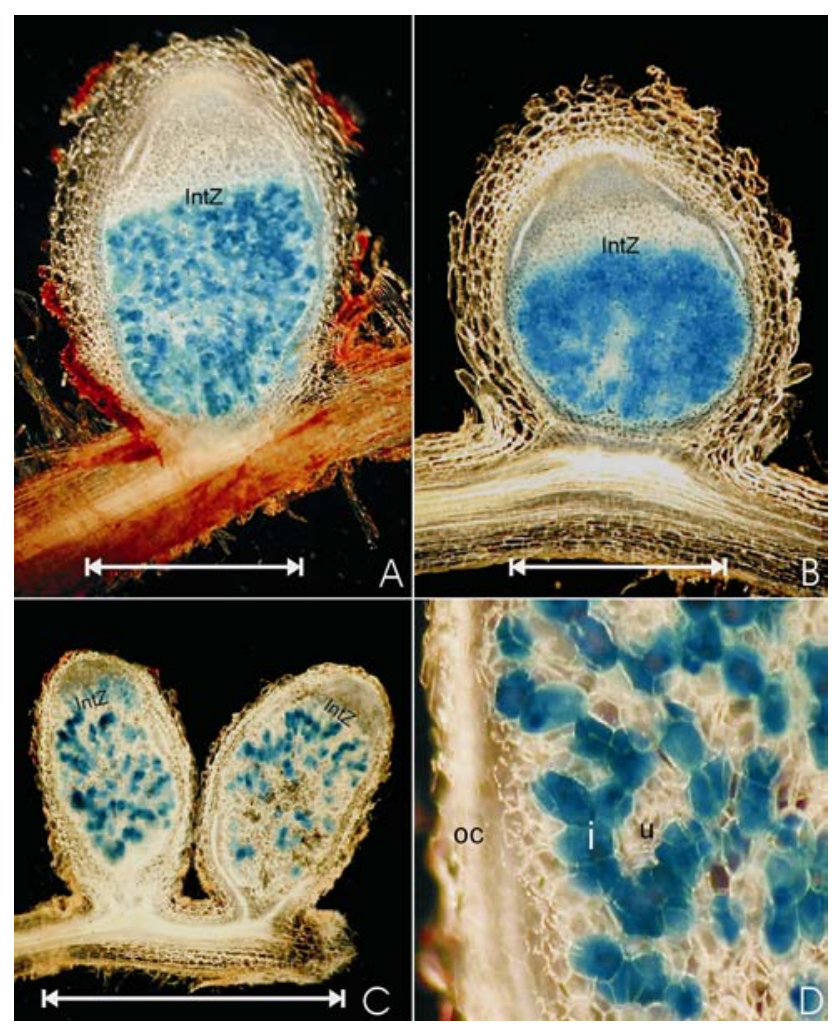

Fig. 2. Histochemical localization of $\beta$-glucuronidase (GUS) activity in 3-week-old nitrogen-fixing nodules of transgenic hairy roots from Vicia faba and Medicago truncatula expressing pVfLb29-gusAint or pVfLb3gusAint. Activity of A, pVfLb29-gusAint and of B, pVfLb3-gusAint shown in a longitudinal semithin section $(80 \mu \mathrm{m})$ of a $V$. faba root nodule, and activity of $\mathbf{C}$, pVfLb29-gusAint shown in a longitudinal semithin section $(80 \mu \mathrm{m})$ of two $M$. truncatula root nodules. GUS activity is located in the infected cells. D, Close-up of the activity of pVfLb29-gusAint in a semithin section $(80 \mu \mathrm{m})$ of a $M$. truncatula root nodule. oc $=$ outer cortex, $\mathrm{u}=$ uninfected cells, $\mathrm{I}=$ infected cells, and int $Z$ = interzone II-III. Bars $=1 \mathrm{~mm}$. 

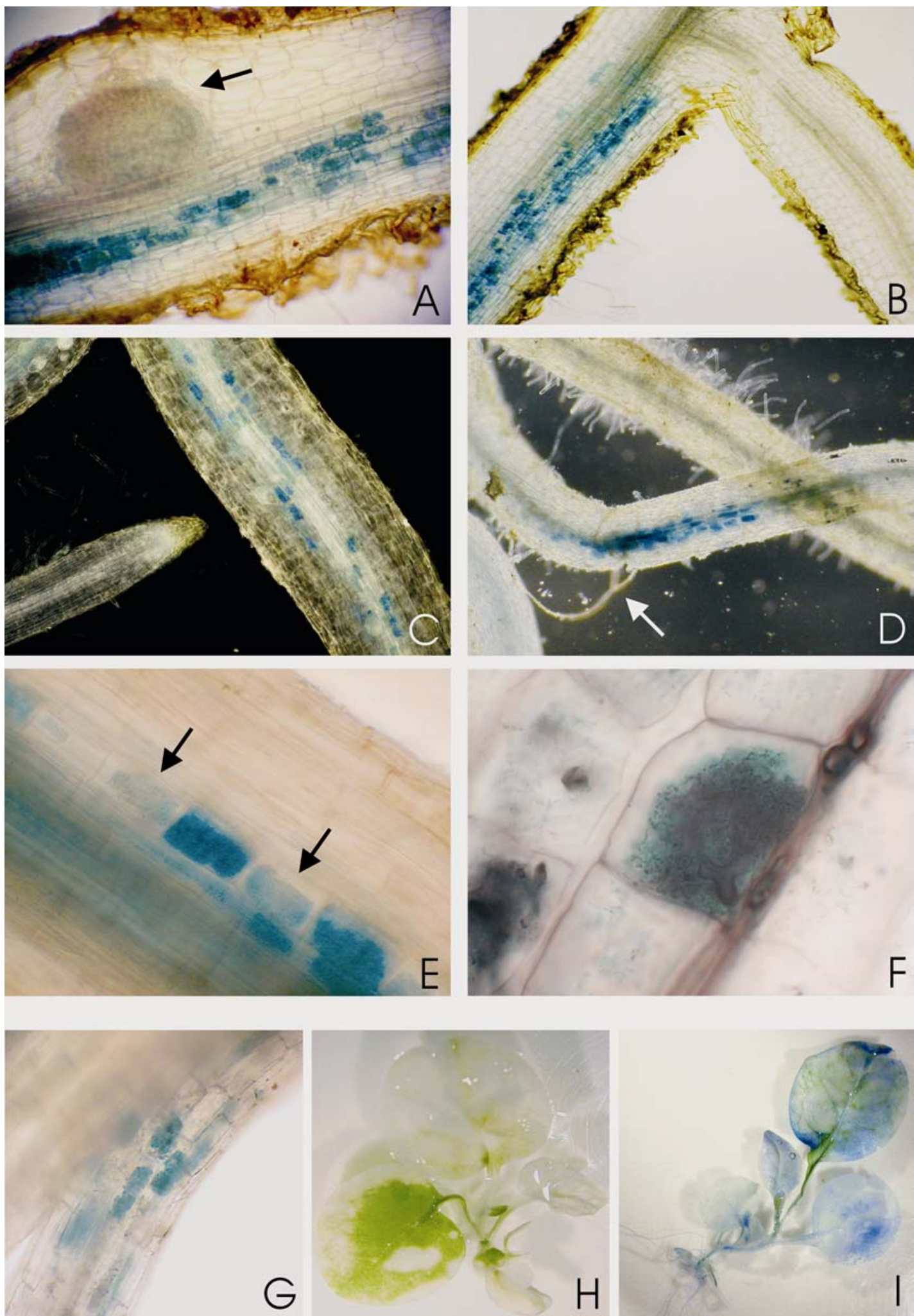

Fig. 3. Histochemical localization of $\beta$-glucuronidase (GUS) activity during mycorrhiza symbiosis in $\mathrm{p} V f$ Lb29-gusAint transgenic hairy roots from Vicia faba, V. hirsuta, and Medicago truncatula and roots of transgenic Nicotiana tabacum expressing pVfLb29-gusAint. A and B, Semithin section (100 $\mu$ m) of a $V$. faba root showing GUS activity restricted to arbuscule-containing cells. The arrow in A indicates a nodule primordium without GUS activity. C, Whole root segment of $V$. hirsuta showing GUS activity in arbuscule-containing cells and the tip of the same root without GUS-staining. D, Whole root segment of M. truncatula showing GUS activity in arbuscule-containing cells. The arrow indicates an extraradical hyphae. E, Closeup of arbusculecontaining cells of M. truncatula. Arrows indicate cells that either show accumulating or disappearing GUS activity. F, Detail of an arbuscule-containing cell of M. truncatula showing GUS activity (blue) after double staining with chlorazole black E for visualization of fungal structures (black). G, Root segment of $N$. tabacum showing GUS activity in arbuscule-containing cells. H, pVfLb29-gusAint transgenic $N$. tabacum shows no GUS activity after hypoxic treatment. I, pGapC4-gusAint transgenic N. tabacum (control) shows GUS activity after hypoxic treatment. Both plantlets (H and I) were treated in the same container at the same time. 
The VfLb29 promoter shows no activity under hypoxic conditions.

Since $\mathrm{Lb}$ are involved in the oxygen supply of bacteroids during nitrogen fixation and since there is evidence that nonsymbiotic hemoglobins are induced in plant tissues under hypoxic conditions (Hunt et al. 2001), a possible activation of the $V f L b 29$ promoter by hypoxia was tested. Both transgenic $N$. $t a-$ bacum lines carrying the pVfLb29-gusAint and the pVfLb3gusAint constructs, respectively, were used for that purpose. As a positive control, transgenic $N$. tabacum plants expressing the gusAint gene under the control of a glycolytic GapC4 promoter from maize (Kohler et al. 1996) were used. The pGapC4-gusAint fusion provides ubiquitous gus expression under hypoxic conditions and was, therefore, a suitable control to study the expression behavior of pVfLb29-gusAint in tobacco. The pVfLb29-gusAint and pVfLb3-gusAint tobacco plants as well as the pGapC4-gusAint control plants were incubated in a container together with a hypoxic reagent for $48 \mathrm{~h}$. After this treatment, the plants were analyzed histochemically for GUS activity in comparison with the untreated counterparts. The hypoxic-treated pGapC4-gusAint control plants showed strong gus expression in all parts of the plant (Fig. 4A), whereas no activity was observed in the untreated counterparts, verifying that hypoxia was established successfully. In

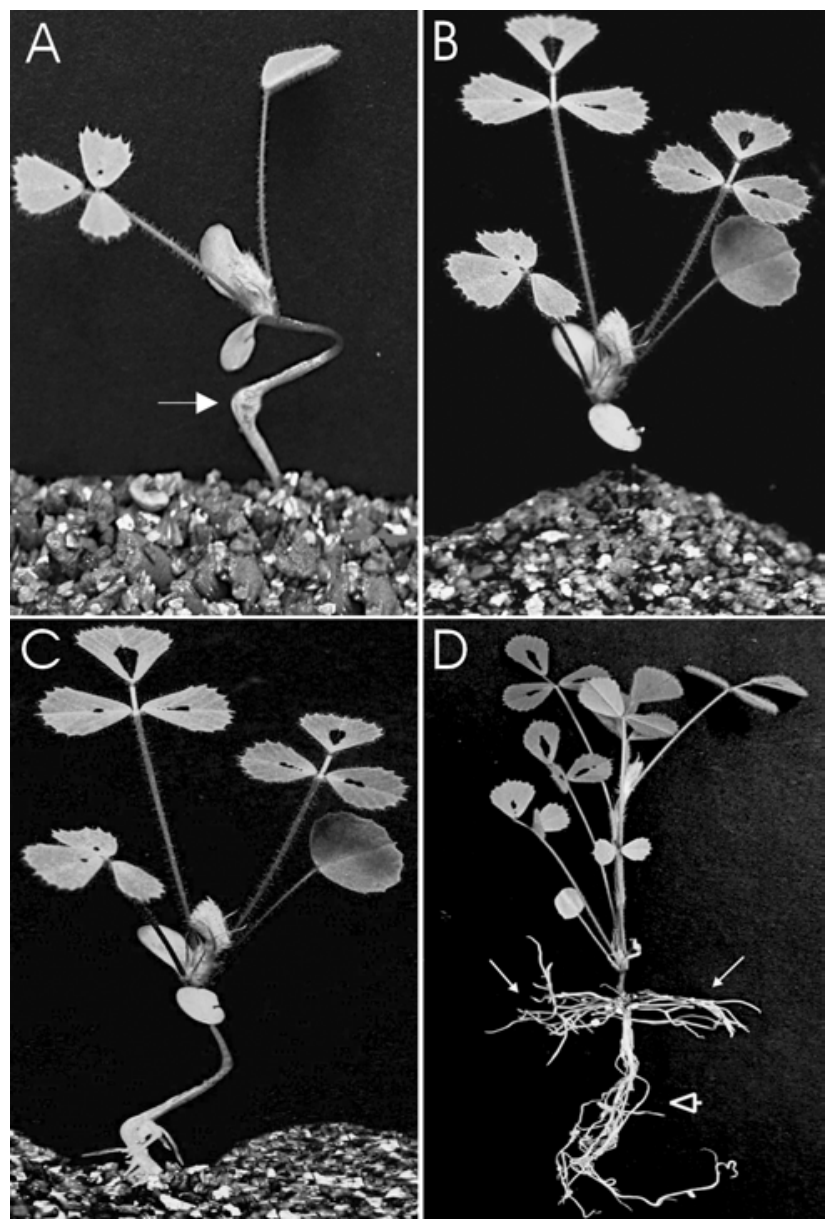

Fig. 4. Induction of hairy roots on Medicago truncatula in open pots. A, Plant 10 days after infection with Agrobacterium rhizogenes. The arrow indicates a swelling formed by callus cells at the inoculation site. $\mathbf{B}$, The inoculation site is covered by a layer of vermiculite/sand. C, Examination of the development of hairy roots. D, Four-week-old plant with nodulated hairy roots. Arrows indicate hairy roots that have developed from the inoculation site, an arrow head marks the wild-type roots. At this stadium, wild-type root can be cut off to exclusively inoculate with the appropriate microsymbionts. the case of the pVfLb29-gus (Fig. 4B) and pVLb3-gus (data not shown) tobacco plants, however, no induction in either treated or untreated plants was visible in all plant tissues. This result shows that hypoxia signals alone are not sufficient to trigger expression of the VfLb29 gene. It has to be noted that apart from arbuscule-containing cells, no GUS activity was observed in any tissue of the transgenic N. tabacum plants (Fig. 3H; data not shown), indicating that the promoter activity is specific for root-symbiotic interactions, at least in this model system.

\section{DISCUSSION}

In this report, we extended the characterization of the $V$. faba leghemoglobin gene VfLb29 that was previously shown to be induced not only in $V$. faba root nodules but also in $V$. faba roots colonized by an endomycorrhizal fungus (Frühling et al. 1997). In accordance with the identification of an OSE-like motif characteristic of symbiotic leghemoglobin genes (Andersson et al. 1997; Stougaard et al. 1987), we observed gus expression in the infected cells of $\mathrm{p} V f L b 29$-gusAint transgenic root nodules of $V$. faba and M. truncatula, allowing us to conclude that VfLb29 exhibits the characteristic cellular expression pattern of a typical leghemoglobin gene. However, in contrast to other Lb, VfLb29 is activated not only in the infected cells of root nodules but also in arbuscule-containing root cells of the legumes $V$. faba, V. hirsuta, and M. truncatula. Since $\mathrm{Lb}$ are proteins typical of nodulating plants, it is interesting that the activation of the VfLb29 promoter in cells carrying an arbuscule is conserved even in the nonlegume Nicotiana tabacum. This finding suggests that there is a common trigger for this promoter in arbuscule-containing root cells of different plant species, which probably relates to the common evolutionary origin of the mycorrhiza symbiosis.

For other nodulin genes activated during both symbiotic interactions, only the gus expression pattern of pMtEnod11gusAint has been presented so far (Journet et al. 2001). For this early nodulin gene, the strongest GUS activity was observed in very early stages of nodule development. In the mature nodule, GUS activity was restricted to the distal end of the nodule, in contrast to $\mathrm{p} V f L b 29$, which showed activation restricted to the infected cells. The observations concerning the activity of $\mathrm{p} M t$ Enod11 during the mycorrhiza symbiosis correlate to some extent with pVfLb29, since both promoters show activation in cells containing arbuscules. However, in contrast to pVfLb29, $\mathrm{pMtEnod} 11$ is also active in early stages of infection with mycorrhizal fungi (Chabaud et al. 2002), and it is additionally activated in some nonsymbiotic tissues (Journet et al. 2001). In case of VfLb29, no activity was observed in nonsymbiotic tissues, e.g., the root tip, as described in the case of $L b c 3$ (Franche et al. 1998), or in earlier stages of rhizobial symbioses, as found for the leghemoglobin gene VsLbl (Heidstra et al. 1997). Apart from arbuscule-containing cells, GUS-staining was not only absent from roots but also from any other tissues of the transgenic pVfLb29-gus N. tabacum plants, suggesting an exclusive induction of the VfLb29 promoter in arbusculecontaining cells in the heterologous system tobacco. Although Northern hybridizations did not reveal VfLb29 expression except for $V$. faba mycorrrhizal roots and root nodules (Frühling et al. 1997), a local expression of the VfLb29 gene in legume tissues outside the root cannot be excluded completely. Nevertheless, it is a true symbiosis-specific gene with respect to the root area. Since arbuscule-containing cells can be looked upon as analogs of the infected cells in the nodule, pVfLb29 is the first promoter shown to be specifically active in the infected cells of both symbiotic interactions. Functional analyses of VfLb29 promoter deletions could elucidate if the same sequence motif is responsible for the activation in infected cells 
of nodules and mycorrhizal roots. A similar specific activity in cells containing an arbuscule as shown here for the VfLb29 promoter has, so far, only been shown for promoters of two phosphate transporter genes, Mtpt4 of M. truncatula (Harrison et al. 2002) and Stpt3 of potato (Rausch et al. 2001). Transgenic roots carrying promoter-gusAint-fusions of these phosphate transporter genes showed gus expression patterns restricted to cells containing arbuscules, as shown for $\mathrm{p} V f L b 29$ gusAint. A sequence motif, which is part of the mycorrhiza and resistance-related element reported by Rausch and associates (2001) for the Stpt3 promoter, was not present in the promoter sequence of VfLb29. However, multiple sequence alignments of the three promoters revealed conserved sequence motifs (data not shown) that might be involved in their activity mediating specific expression in cells carrying an arbuscule. In combination with analyses using promoter deletions, these putative motifs could lead to the identification of common specific sequence motifs concerning the activation of plant promoters in arbuscule-containing cells.

By investigating the GUS activity of transgenic N. tabacum plants harboring a promoter-gus fusion of VfLb29 under hypoxia, we were able to exclude an induction of VfLb29 within the frame of a hypoxic response, as shown for nonsymbiotic hemoglobin genes (Hunt et al. 2001). This implies that, although the VfLb29 protein might be involved in the oxygen supply as it is known for other Lb (Appleby 1984), the VfLb29 gene is apparently not exclusively induced by this trigger.

The role of Lb to ensure the oxygen supply of microsymbionts in the root nodule has been well documented (Appleby 1984; Layzell and Hunt 1990). Thus, if we interpret arbusculecontaining cells as analogs of the infected cells in the root nodule, the most obvious role for a Lb in this context is to supply oxygen for the microsymbiont or to prevent the cell from running out of oxygen. The VfLb29 gene, however, is outstanding amongst the other $V$. faba leghemoglobin genes because its deduced amino acid sequence differs from these by 32 to $38 \%$ (Frühling et al. 1997). Nevertheless, based on its expression pattern and the organ-specific element in the promoter sequence, this hemoglobin gene was classified as a leghemoglobin gene. This classification, however, does not exclude the possibility that the VfLb29 protein exhibits similarities to the nonsymbiotic hemoglobins concerning the oxygen-binding kinetics. The affinity of nonsymbiotic hemoglobins for oxygen is much higher compared with $\mathrm{Lb}$, resulting in a very slow release of the bound molecule (Duff et al. 1997). Only little is known about the role of the nonsymbiotic hemoglobins so far, but they are supposed to have several functions in different tissues (Arredondo-Peter et al. 1998). Expression in stressed tissues seems to be their common characteristic, and a role for the maintenance of metabolism under oxygen-limited conditions in these tissues is most likely (Arredondo-Peter et al. 1998; Hill 1998). Considering this, the function of VfLb29 could also be related to support metabolism under oxygen-limiting conditions.

However, several other potential functions and multiple roles in different tissues can be postulated for plant Lb, e.g., the ability to bind nitric oxide (NO). NO, which is highly reactive and toxic, is produced in plant tissues due to various factors, and its role in plants is currently a point of discussion (Herouart 2002; Wojtaszek 2000). The synthesis of NO in the root nodule and its inhibitory effect on nitrogenase activity has already been demonstrated (Trinchant 1982). For animals, the reaction of NO with blood hemoglobin is considered to be the major route of detoxification (Wennmalm et al. 1992), which might be the same also for plants (Dordas et al. 2003). Thus, it seems to be possible that a hemoglobin protein could also be involved in the detoxification of nitric oxide that is produced in the frame of the altered metabolism in the infected cells of nodules and mycorrhizal roots. Furthermore, NO is known to be involved in plant defense response against pathogens. Application of exogenous NO to plant tissues proved to trigger programmed cell death and defense gene induction. In accordance with that, NO scavengers were able to suppress defense response (Delledonne et al. 1998; Durner et al. 1998). Considering that plant defense response has to be suppressed in symbiotic interactions, a hemeprotein could possibly act as a NO scavenger and contribute to the defense suppression process, both in the root nodule and in cells containing an arbuscules. In a recent publication, Uchiumi and associates (2002) also come to a similar conclusion. It should be noted that there is evidence that processes concerning the defense suppression take place specifically in cells containing an arbuscule, since an induction of several genes related to defense suppression was already shown to occur exclusively in these cells (Blee and Anderson 1996; Bonanomi et al. 2001; Salzer et al. 1999).

The hypotheses mentioned above show that there are several plausible explanations for the induction of a $\mathrm{Lb}$ gene in the context of plant-microbe symbioses. Nevertheless, it remains to be evaluated if this protein is present in meaningful amounts in the infected cells of root nodules and in the arbuscule-containing root cells of legumes. Since the possible function of VfLb29 in these cells depends on its binding properties for oxygen, further investigations concerning the biochemical characteristics of VfLb29 need to be carried out to elucidate its function in the nodule and mycorrhiza symbiosis.

\section{MATERIALS AND METHODS}

\section{Plant material and microbial strains.}

For the induction of hairy roots $V$. faba cv. Kleine Thueringer (University of Bielefeld, Germany), V. hirsuta (University of Bielefeld, Germany) and M. truncatula cv. Jemalong A17 (T. Huguet, INRA, Toulouse, France) were used. Leaf disks of $N$. tabacum cv. SAM (University of Bielefeld, Germany) were used for generating $\mathrm{p} V f L b 29$ and $\mathrm{p} V f L b 3$ transgenic tobacco, performed according to standard procedures (Rosahl et al. 1987). Transgenic tobacco harboring the hypoxic-inducible GapC4 promoter-gus fusion (Kohler et al. 1996) was provided by R. Hehl (Technical University Braunschweig, Germany).

A. rhizogenes Arqua1 (Quandt et al. 1993) and A. tumefaciens EHA 105 (Hood et al. 1993) were used for the induction of hairy roots and for the tobacco leaf-disk transformation, respectively. Nodules were induced on 12- to 14-day-old transgenic hairy roots of $V$. faba by $R$. leguminosarum VF39 (Priefer 1989) and, in the case of M. truncatula, by S. meliloti 1021 (Casse et al. 1979). Inoculations with $G$. intraradices were carried out with a commercially available inoculum based on aseptic liquid medium containing spores (Premier Tech Biotechnologies, Rivière-de-Loup, Québec, Canada).

\section{Construction of the $V f L b 29$ \\ and $V f L b 3$ promoter-gusAint fusions.}

The VfLb3 promoter ( -2003 to -1 in relation to the ATG) was inserted as a $C l a \mathrm{I} / E c o$ RI fragment in the plasmid pGUSINT (Küster et al.1995), and the pVfLb3-gusAint fusion was subsequently cloned as a SpeI fragment in plasmid pIV2 (Küster et al.1995). This plasmid was used to integrate the fusion into the T-DNA of the Ri plasmid of A. rhizogenes Arqua1 (Quandt et al. 1993) by single cross-over. Two fragments of the VfLb29 promoter $(1,261$ to -31 and -87 to -31 in relation to the ATG) were inserted as an EcoRI/SalI fragment in plasmid pGUS-INT, and these pVfLb29-gusAint fusions were subsequently cloned as a SalI fragment in plasmid pIV2. The resulting plasmids were used to integrate the fusions into the T-DNA 
of the Ri plasmid of A. rhizogenes Arqual (Quandt et al., 1993) by single cross-over. The A. tumefaciens-mediated transformation of $N$. tabacum was carried out using derivatives of the binary vector pBIN19 carrying the $L b$ promoter-gusAint fusions. In the case of the pVfLb3-gusAint fusion, a SpeI fragment was cloned into the $X b a$ I site of pBIN19, whereas in the case of the pVfLb29-gusAint fusions, SalI fragments were cloned into the SalI site of BIN19.

\section{Plant growth conditions and induction of transgenic hairy roots \\ on V. faba, V. hirsuta, and M. truncatula.}

The following protocol for the induction of hairy roots in open pots was originally developed for $V$. faba, since this species is difficult to cultivate under sterile conditions, due to its size. However, this method also proved to be a simple and efficient way to induce hairy roots on other legume species, such as Pisum sativum (data not shown), V. hirsuta, and most remarkable, $M$. truncatula. It could thus be an interesting alternative to the well-established in vitro method for inducing hairy roots on $M$. truncatula described by Boisson-Dernier and associates (2001).

Scarification of M. truncatula and V. hirsuta seeds with $\mathrm{H}_{2} \mathrm{SO}_{4}$ was carried out as described by Quandt and associates (1993). Scarification of V. faba seeds is not necessary. M. truncatula and $V$. faba seeds were spread out for germination in pots with humid vermiculite/perlite (1:1) and were incubated in the dark at $24^{\circ} \mathrm{C}$ for about $48 \mathrm{~h}$. Afterwards, they have to be kept to $4^{\circ} \mathrm{C}$ for at least three days to make the tissue of the seedlings more susceptible to inoculation with agrobacteria. Seedlings were then planted into small pots with vermiculite/perlite (1:1) fertilized with $1 / 2$ strength Hoagland's solution (Arnon and Hoagland 1940). The plants were now inoculated with $A$. rhizogenes carrying the $L b$ promoter-gusAint fusions integrated into the T-DNA. An inoculation with $A$. rhizogenes grown in liquid media is not possible, since this would lead to rotting symptoms on the inoculation site. Thus, the bacteria were grown on petri dishes with the appropriate antibiotics for $24 \mathrm{~h}$ at $30^{\circ} \mathrm{C}$. The agrobacteria were scraped off the petri dish and were resolved in $1 \mathrm{ml}$ of sterile PS buffer. The $V$. faba and $V$. hirsuta seedlings were inoculated by an injection three times parallel to the vascular bundle of the epicotyl, as described for $V$. hirsuta by Quandt and associates (1993). In the case of $M$. truncatula, the injection was performed at the white part of the hypocotyl. The plantlets were then set under a plastic cover for about two days in the growth chamber at $20^{\circ} \mathrm{C}$. After about 10 days, small swellings formed by callus cells became visible at the inoculation site (Fig. 4A, arrow). These parts were covered by a layer of vermiculite/sand (1:1) (Fig. 4B), and the temperature was set up to $22^{\circ} \mathrm{C}$. In the following time, the plants developed hairy roots, which could be examined by careful removal of the vermiculite/sand (Fig. 4C). After hairy roots developed, all roots that did not emerge from the infection site (Fig. 4D, arrows indicate hairy roots, arrow head wild-type roots) were removed, and the plants were planted into bigger pots for inoculation with appropriate microbes. Apart from the exceptions mentioned before, all plants used for this study were grown in the growth chamber under a 16-h light $\left(22^{\circ} \mathrm{C}\right)$ and 8 -h dark $\left(18^{\circ} \mathrm{C}\right)$ regime.

Typical frequencies of hairy root formation at the inoculation site were about $70 \%$ with about $75 \%$ of the roots expressing the transgene (data for M. truncatula).

\section{Histochemical analysis of transgenic tissues.}

Histochemical assays for GUS activity were performed as described by Jefferson et al. (1987). The GUS substrate solution contained $2 \mathrm{mM}$ X-Gluc (5-bromo-4-chloro-3-indolyl- $\beta$-D- glucuronide cyclohexylammonium salt; Biosynth, Switzerland), $2 \mathrm{mM}$ potassium ferricyanide, $100 \mathrm{mM}$ Tris, $\mathrm{pH}$ 7.0, $50 \mathrm{mM}$ sodium chloride, $\mathrm{pH} 7.0$, and $0.1 \%$ Tween-20. Roots were vacuum-infiltrated prior to incubation in the dark at $37^{\circ} \mathrm{C}$ for 1 to $24 \mathrm{~h}$. GUS assays of hairy roots expressing promoter-gus Aint fusions were performed four weeks after nodulation and 25 days after inoculation with $G$. intraradices.

For staining of fungal structures, roots were first cleared with $10 \% \mathrm{KOH}$ (wt/vol, potassium hydroxide dissolved in water) for $10 \mathrm{~min}$ at $90^{\circ} \mathrm{C}$ and were subsequently assayed by $0.03 \% \mathrm{wt} / \mathrm{vol} \mathrm{CBE}$ in a lactoglycerol solution $(1: 1: 1$, lactic acid/glycerol/water) for $4 \mathrm{~h}$ at $90^{\circ} \mathrm{C}$, as described by Brundrett and associates (1984). Prior to observation, the roots were destained with $50 \% \mathrm{vol} / \mathrm{vol}$ glycerol for several days.

Before the GUS-staining of mycorrhizal roots and root nodules, semithin sections (80 to $120 \mu \mathrm{m})$ were prepared with a microtome (Leica VT/000S; Wetzlar, Germany). Examination of tissues was carried out by light microscopy (Olympus BH-2; Hamburg, Germany), and documentation was done using a digital camera (Olympus C-2000Z).

\section{Stress treatment.}

For hypoxic induction, plants were incubated in an air-tight glass container (Merck; Darmstadt, Germany), together with Anaerocult A (Merck) for $48 \mathrm{~h}$. The establishment of a hypoxic atmosphere was verified by Anaerotest stripes (Merck).

\section{ACKNOWLEDGMENTS}

We thank the Deutsche Forschungsgemeinschaft for supporting this work in the frame of the Molmyk project (Pe814/1-2). We thank R. Hehl (Technical University, Braunschweig, Germany) for seeds of the transgenic tobacco plants harboring the hypoxic-inducible GapC4 promotergus fusion.

\section{LITERATURE CITED}

Albrecht, C., Geurts, R., Lapeyrie, F., and Bisseling, T. 1998. Endomycorrhizae and rhizobial Nod factors both require SYM8 to induce the expression of the early nodulin genes PSENOD5 and PSENOD12A. Plant J.15:605-614.

Alexander, T., Toth, R., Meier, R., and Weber, H. C. 1989. Dynamics of arbuscule development and degeneration in onion, bean, and tomato with reference to vesicular-arbuscular mycorrhizae in grasses. Can. J. Bot. 67:2505-2513

Andersson, C. R., Jenson, E. O., Llewellyn, D. J., Dennis, E. S., and Peacock, W. J. 1996. A new hemoglobin gene from soybean: A role for hemoglobin in all plants. Proc. Natl. Acad. Sci. U.S.A. 93:5682-5687.

Andersson, C. R., Llewellyn, D. J., Peacock, W. J., and Dennis, E. S. 1997. Cell-specific expression of the promoters of two nonlegume hemoglobin genes in a transgenic legume, Lotus corniculatus. Plant Physiol. 113:45-57.

Appleby, C. A. 1984. Leghemoglobin and rhizobium respiration. Ann. Rev. Plant Physiol. 35:443-476.

Arnon, D. I., and Hoagland, D. R. 1940. Crop production in artificial culture solutions and in soils with special reference to factors influencing yields and absorption of inorganic nutrients. Soil Sci. 50:463-483.

Arredondo-Peter, R., Hargrove, M. S., Moran, J. F., Sarath, G., and Klucas, R. V. 1998. Plant hemoglobins. Plant Physiol. 118:1121-1125.

Blee, K. A., and Anderson, A. J. 1996. Defense-related transcript accumulation in Phaseolus vulgaris L. colonized by the arbuscular mycorrhizal fungus Glomus intraradices. Plant Physiol. 110:675-688.

Boisson-Dernier, A., Chabaud, M., Garcia, F., Bécard, G., Rosenberg, C. and Barker, D.G. 2001. Agrobacterium rhizogenes-transformed roots of Medicago truncatula for the study of nitrogen-fixing and endomycorrhizal symbiotic associations. Mol. Plant-Microbe Interact. 14:695700 .

Bonanomi, A., Wiemken, A., Boller, T., and Salzer, P. 2001. Local induction of a mycorrhiza-specific class III chitinase gene in cortical root cells of Medicago truncatula containing developing or mature arbuscules. Plant Biol. 3:194-199.

Brundrett, M. C., Piché, Y., and Peterson, R. L. 1984. A new method for observing morphology of vesicular-arbuscular mycorrhizae. Can. J. Bot. 62:2128-2134. 
Casse, F., Boucher, D., Julliot, J. S., Michel, M., and Denarie, J. 1979. Identification and characterization of large plasmids in Rhizobium meliloti using agarose gel electrophorese. J. Gen. Microb. 113:229-242.

Chabaud, M., Venard, C., Defaux-Petras, A., Bécard, G. and Barker, D. G. 2002. Targeted inoculation of Medicago truncatula in vitro root cultures reveals $M t E N O D 11$ expression during early stages of infection by arbuscular mycorrhizal fungi. New Phytol. 156:265-273.

Christensen, T., Dennis, E. S., Peacock, W. J., Landsmann, J., and Marcker, K. A.1991. Hemoglobin genes in non-legumes: Cloning and characterization of a Casuarina glauca hemoglobin gene. Plant Mol. Biol. 16:339-344

Delledonne, M., Xia, Y. J., Dixon, R. A., and Lamb, C. 1998. Nitric oxide functions as a signal in plant disease resistance. Nature 394:585-588.

Dickson, S., and Smith, S. E. 2001. Cross walls in arbuscular trunk hyphae form after loss of metabolic activity. New Phytol. 151:735-742.

Dordas, C., Rivoal, J., and Hill, R. D. Submitted for publication.

Duc, G., Trouvelot, A., Gianinazzi-Pearson, V., and Gianinazzi, S. 1989 First report of non-mycorrhizal plant mutants $\left(\mathrm{myc}^{-}\right)$obtained in pea (Pisum sativum L.) and faba bean (Vicia faba L.). Plant Sci. 60:215222

Duff, S. M. G., Wittenberg, J. B., Nie, X. H., and Hill, R. D. 1997. Ligand binding kinetics and expression of recombinant and nonrecombinant barley hemoglobin. Plant Physiol. Suppl. S 114:449-449.

Durner J., Wendehenne D., and Klessig, D. F. 1998. Defense gene induction in tobacco by nitric oxide, cyclic GMP, and cyclic ADP-ribose. Proc. Natl. Acad. Sci. U.S.A. 95:10328-10333.

Fedorova, M., van de Mortel, J., Matsumoto, P. A., Cho, J., Town, C. D., VandenBosch, K. A., Gantt, J. S., and Vance, C. P. 2002. Genome-wide identification of nodule-specific transcripts in the model legume Medicago truncatula. Plant Physiol.130:519-537.

Franche, C., Diouf, D., Laplaze, L., Auguy, F., Frutz, T., Rio, M., Duhoux, E., and Bogusz, D. 1998. Soybean (lbc3), Parasponia, and Trema hemoglobin gene promoters retain symbiotic and nonsymbiotic specificity in transgenic Casuarinaceae: Implications for hemoglobin gene evolution and root nodule symbioses. Molecular Plant-Microbe Interactions 11:887-894.

Frühling, M., Roussel, H., Gianinazzi-Pearson, V., Pühler, A., and Perlick, A. M. 1997. The Vicia faba leghemoglobin gene VfLb29 is induced in root nodules and in roots colonized by the arbuscular mycorrhizal fungus Glomus fasciculatum. Mol. Plant-Microbe Interact. 10:124-131

Gallusci, P., Dedieu, A., Journet, E.-P., Huguet, T., and Barker, D. G 1991. Synchronous expression of leghemoglobin genes in Medicago truncatula during nitrogen-fixing root nodule development and response to exogenously supplied nitrate. Plant Mol Biol. 17:335-349.

Gianinazzi-Pearson, V. 1996. Plant cell responses to arbuscular mycorrhizal fungi: Getting to the roots of the symbiosis. Plant Cell 8:1871-1883.

Gianinazzi-Pearson, V. 1997. Have common plant systems co-evolved in fungal and bacterial root symbioses? Pages 321-324 in: Biological Fixation of Nitrogen for Ecology and Sustainable Agriculture: NATTOASI Series. Vol. G39. A. Legocki, H. Bothe, and A. Puhler, eds. Springer-Verlag, Berlin.

Harley, J. L., and Smith, S. E.1983. Page 483 in: Mycorrhizal Symbiosis. Academic Press Inc., London.

Harrison, M. J., Dewbre, G. R., and Liu, J. Y. 2002. A phosphate transporter from Medicago truncatula involved in the acquisition of phosphate released by arbuscular mycorrhizal fungi. Plant Cell 14:2413-2429.

Harrison, M. J. 1999. Molecular and cellular aspects of the arbuscular mycorrhizal symbiosis. Ann. Rev. Plant Physiol. Plant Mol. Biol. 50:361-389.

Heidstra, R., Nilsen, G., Martinez-Abarca, F., van Kammen, A., Bisseling, T. 1997. Nod factor-induced expression of leghemoglobin to study the mechanism of $\mathrm{NH}_{4} \mathrm{NO}_{3}$ inhibition on root hair deformation. Mol. Plant-Microbe Interact. 10: 215-220

Herouart, D., Baudouin, E., Frendo, P., Harrison, J., Santos, R., Jamet, A., Van de Sype, G., Touati, D., and Puppo, A. 2002. Reactive oxygen species, nitric oxide and glutathione: A key role in the establishment of the legume-rhizobium symbiosis? Plant Physiol. Biochem. 40:619-624.

Hill, R. D. 1998. What are hemoglobins doing in plants? Can. J. Bot. 76:707-712.

Hood, E. E., Gelvin, S. B., Melchers, L. S., and Hoekema, A. 1993. New agrobacterium helper plasmids for gene-transfer to plants. Transgene Res. 2:208-218

Hunt, P. W., Watts, R. A, Trevaskis, B., Llewelyn, D. J., Burnell, J., Dennis, E. S., and Peacock, W. J. 2001. Expression and evolution of functionally distinct haemoglobin genes in plants. Plant Mol. Biol. 47:677-692.

Jacobsen-Lyon, K., Jensen, E. O., Jørgensen, J. E., Marcker, K. A., Peacock, W. J., and Dennis, E. S.1995. Symbiotic and non-symbiotic haemoglobin genes in Casuarina glauca. Plant Cell. 7:213-233.

Jefferson, R. A., Kavanagh, T. A., and Bevan, M. W. 1987. GUS fusions: $\beta$-glucuronidase as a sensitive and versatile gene fusion marker in higher plants. EMBO (Eur. Mol. Biol. Organ.) J. 6:3901-3907.

Jeffries, P. 1987. Uses of mycorrhizae in agriculture. Crit. Rev. Biotechnol. 5:319-357.

Journet, E. P., El-Gachtouli, N., Vernoud, V., de Billy, F., Pichon, M., Dedieu, A., Arnould, C., Morandi, D., Barker, D. G., and GianinazziPearson, V. 2001. Medicago truncatula ENOD11: A novel RPRPencoding early nodulin gene expressed during mycorrhization in arbuscule-containing cells. Mol. Plant-Microbe Interact. 14:737-748.

Kohler, U., Mendel, R. R., Cerff, R., and Hehl, R. 1996. A promoter for strong and ubiquitous hypoxic gene expression in tobacco. Plant $\mathrm{J}$. 10:175-183.

Küster, H., Quandt, H.-J., Broer, I., Perlick, A. M., and Pühler, A. 1995. The promoter of the Vicia faba L. VfENOD-GRP3 gene encoding a glycine-rich early nodulin mediates a predominant gene expression in the interzone II-III region of transgenic Vicia hirsuta root nodules. Plant Mol. Biol. 29:759-772.

Layzell, D. B., and Hunt, S. 1990. Oxygen and regulation of nitrogen fixation in legumes nodules. Physiol. Plant. 80:322-327.

Metz, B. A., Welters, P., Hoffmann, H. J., Jensen, E. O., Schell, J., and de Bruijn, F. 1988. Primary structure and promoter analysis of leghemoglobin genes of the stem-nodulated tropical legume Sesbania rostrata: Conserved coding sequences, cis-elements and trans-acting factors. Mol. Gen. Genet.:214, 181.

Priefer, U. B. 1989. Genes involved in lipopolysaccharide production and symbiosis are clustered on the chromosome of Rhizobium leguminosarum biovar viciae VF39. J. Bacteriol. 171:6167-6168.

Provorov, N. A., Borisov, A. Y., and Tikhonovich, I. A. 2002. Developmental genetics and evolution of symbiotic structures in nitrogen-fixing nodules and arbuscular mycorrhiza. J. Theor. Biol. 214:215-232.

Quandt, H. J., Pühler, A., and Broer, I. 1993. Transgenic root nodules of Vicia hirsuta: A fast and efficient system for the study of gene expression in indeterminate-type nodules. Mol. Plant-Microbe Interact. 6:699-706.

Rausch, C., Daram, P., Brunner, S., Jansa, J., Laloi, M., Leggewie, G., Amrhein, N., and Bucher, M. A. 2001. A phosphate transporter expressed in arbuscule-containing cells in potato. Nature 414:462-466.

Rosahl, S., Schmidt, R., Schell, J., and Willmitzer, L.1987. Expression of a tuber-specific storage protein in transgenic tobacco plants: Demonstration of an esterase activity. EMBO (Eur. Mol. Biol. Organ.) J. 6:1155-1159.

Salzer, P., Corbiere, H., and Boller, T. 1999. Hydrogen peroxide accumulation in Medicago truncatula roots colonized by the arbuscular mycorrhiza-forming fungus Glomus intraradices. Planta 208:319-325.

Seregelyes, C., Mustardy, L., Ayaydin, F., Sass, L., Kovacs, L., Endre, G., Lukacs, N., Kovacs, I., Vass, I., Kiss, G. B., Horvath, G. V., and Dudits, D. 2000. Nuclear localization of a hypoxia-inducible novel non-symbiotic hemoglobin in cultured alfalfa cells. FEBS (Fed. Eur. Biochem. Soc.) Letters 1-2:125-130.

Stougaard, J., Sandal, N., Gron, A., Kuhle, A., and Marcker, K. 1987. $5^{\prime}$ analysis of the soybean leghaemoglobin $l b c 3$ gene: Regulatory elements required for promoter activity and organ specificity. EMBO (Eur. Mol. Biol. Organ.) J. 6:3565-3569.

Trevaskis, B., Watts, R. A., Andersson, C. R, Llewellyn, D. J., Hargrove, M. S., Olson, J. S., Dennis, E. S., and Peacock, W. J. 1997. Two hemoglobin genes in Arabidopsis thaliana: The evolutionary origins of leghemoglobins. Proc. Natl. Acad. Sci. U.S.A. 94 :12230-12234.

Trinchant, J. G., and Rigaud, J. 1982. Nitrite and nitric oxide as inhibitors of nitrogenase from soybean bacteroid. Appl. Environ. Microbiol. 44:1385-1388

Uchiumi, T., Shimoda, Y., Tsuruta, T., Mukoyoshi, Y., Suzuki, A., Senoo, K., Sato, S., Kato, T., Tabata, S., Higashi, S., and Abe, M. 2002. Ex pression of symbiotic and nonsymbiotic globin genes responding to microsymbionts on Lotus japonicas. Plant and Cell Physiol. 43:13511358.

VanRhijn, P., Fang, Y., Galili, S., Shaul, O., Atzmon, N., Wininger, S., Eshed, Y., Lum, M., Li, Y., To, V., Fujishige, N., Kapulnik, Y., and Hirsch, A. M. 1997. Expression of early nodulin genes in alfalfa mycorrhizae indicates that signal transduction pathways used in forming arbuscular mycorrhizae and rhizobium-induced nodules may be conserved. Proc. Natl. Acad. Sci. U.S.A. 94:5467-5472.

Watts, R. A, Hunt, P. W, Hvitved, A. N, Hargrove, M. S, Peacock, W. J, and Dennis, E. S. 2001. A hemoglobin from plants homologous to truncated hemoglobins of microorganisms. Proc. Natl. Acad. Sci. U.S.A. 98:10119-10124.

Wojtaszek, P. 2000. Nitric oxide in plants-To NO or not to NO. Phytochem. 1:1-4

Wennmalm, A., Benthin, G., and Petersson, A. S. 1992. Dependence of the metabolism of nitric oxide in healthy human whole blood on the oxygenation of its red cell haemoglobin. Br. J. Pharmacol. 106:507-508. 